\title{
Antimicrobial activity of ethyl acetate extracts of Streptomyces sp. CRB46 and the prediction of their bioactive compounds chemical structure
}

\author{
AMBARWATI AMBARWATI ${ }^{1, \bullet}$, SUBAGUS WAHYUONO ${ }^{2}$, SUKARTI MOELJOPAWIRO ${ }^{3}$, \\ TRIWIBOWO YUWONO ${ }^{4, v}$ \\ ${ }^{1}$ Department of Public Health, Faculty of Health Sciences, Universitas Muhammadiyah Surakarta. J1. Ahmad Yani, Kartasura, Sukoharjo 57102, Jawa \\ Tengah, Indonesia. Tel.: +62-271-717417, Fax.: +62-271-715448, `email: ambarwati@ums.ac.id \\ ${ }^{2}$ Laboratory of Biology Pharmacy, Faculty of Pharmacy, Universitas Gadjah Mada. Jl. Sekip Utara, Sleman 55281, Yogyakarta, Indonesia \\ ${ }^{3}$ Laboratory of Biochemistry, Faculty of Biology, Universitas Gadjah Mada. Jl. Teknika Selatan, Sleman 55281, Yogyakarta, Indonesia \\ ${ }^{4}$ Department of Agricultural Microbiology, Faculty of Agriculture, Universitas Gadjah Mada. Jl. Flora, Bulaksumur, Sleman 55281, Yogyakarta, \\ Indonesia. Tel.: +62-274-563062, Fax.: +62-274-563062, ^vemail: triwibowo_y@ugm.ac.id
}

Manuscript received: 21 March 2020. Revision accepted: 29 June 2020.

\begin{abstract}
Ambarwati A, Wahyuono S, Moeljopawiro S, Yuwono T. 2020. Antimicrobial activity of ethyl acetate extracts of Streptomyces sp. CRB46 and the prediction of their bioactive compounds chemical structure. Biodiversitas 21: 3380-3390. The goal of the research was to determine the antimicrobial activity of ethyl acetate extracts of Streptomyces sp. CRB46 and predict their chemical structure of the bioactive compounds based on the AntiSMASH analysis of the whole genome sequencing. Streptomyces sp. CRB46 was isolated from Cyperus rotundus L. rhizosphere in the Cemoro Sewu highland, Indonesia (1920 meters above sea level). The results showed that the supernatant ethyl acetate (EAS) extract could inhibit 11 of 12 tested microorganisms with a diameter of the inhibition zone ranging from 17-35 mm (paper disc method). The supernatant extract was found more effective in inhibiting microorganisms than the ethyl acetate extract of pellets (EAP). The EAP extract was only able to inhibit the growth of seven tested microorganisms (16-26 mm). The results of LCMS analysis showed that crude extract of EAS consisted of 20 mixtures of organic compounds. Based on FTIR analysis, 16 functional groups were found in the EAS extracts. In addition, based on AntiSMASH analysis, it was also found that Streptomyces sp. CRB46 produced eight classes of bioactive compounds, but only six compounds have been identified as their chemical structures. It can, therefore, be concluded that Streptomyces sp. CRB46 has the potential to produce bioactive compounds that can be used for microbial infection treatment.
\end{abstract}

Keywords: Antimicrobial activity, antiSMASH, Cyperus rotundus, rhizosphere, Streptomyces

\section{INTRODUCTION}

Many studies have been carried out to obtain new antibiotics from various types of microorganisms, but the previous studies are mainly focused on the genus Streptomyces. This fact may be attributed to the fact that Streptomyces are known as the biggest secondary bioactive metabolites compound producer, especially antibiotics. About $75-80 \%$ of the antibiotics that have been found are produced by Streptomyces (Arifuzzaman et al. 2010; Ullah et al. 2012).

Currently, 4,000 antibiotics are produced by bacteria, fungi, and Streptomyces (Okami and Hotta 1988; KornWendisch and Kutzner 1992). Fifty percent of 10,000 bioactive compounds are produced by Streptomyces species (Anderson and Wellington 2001). More than 500 types of antibiotics have been produced by Streptomyces, 60 types of antibiotics have found many applications in medicine, agriculture, and industry (Madigan et al. 2003). Based on the data of the Italian Antibiotic Literature Database (ALD), among 8000 antimicrobials, $45.6 \%$ are produced by Streptomyces, and only $21.5 \%$ are produced by fungi, $16.9 \%$ from other bacteria, and $16 \%$ from other Actinomycetes (Lazzarini et al. 2000).
Isolation of antibiotic-producing Streptomyces from soil has been widely carried out; however, not many attention has been focused on the use of soils from the highlands as the microbial source. The highland plateau is one of the extreme habitats for microorganisms. It is generally understood that microorganisms thrive in extreme environments have the ability to produce bioactive compounds (Sivalingam et al. 2019). The aim of this study was to determine the antimicrobial activity of ethyl acetate extracts of Streptomyces sp. CRB46, isolated from the rhizosphere of Cyperus rotundus L. grew in Cemoro Sewu highland, and to suggest the chemical structures of the bioactive compounds. Previous research has demonstrated that the ethyl acetate extract of two Actinomycetes isolates from the Torosiaje mangrove forest, Gorontalo has the potential to inhibit the growth of pathogenic microorganisms. The bioautography results show that the active compound from one isolate, namely FUAm2-h1, has an Rf value of 0.94 (Retnowati et al. 2018). Another study has shown that the supernatant crude extract of rhizospheric actinomycetes also inhibits the growth of urinary tract infections bacteria (Apsari et al. 2019).

The advances in DNA sequencing technology combined with bioinformatics (genome mining) enable the 
rapid identification of gene clusters that encode secondary bioactive compounds and make predictions of the chemical structure of these bioactive compounds based on gene sequence information (Farnet and Zazopoulos 2005). At present, various web-based bioinformatics technologies have been developed, including the Antibiotics and Secondary Metabolite Analysis (AntiSMASH) (Blin et al. 2019). AntiSMASH bioinformatics technology can provide data for the identification of gene clusters that specifically encode antibiotics and other bioactive compounds. The previous research, based on the AntiSMASH version 3.0 analysis, shows that Streptomyces sp. GMR22 isolated from Cajuput rhizospheric soil at Wanagama Forest has 63 gene clusters that encode the biosynthesis of secondary metabolites (Herdini et al. 2017).

\section{MATERIALS AND METHODS}

\section{Collection of soil sample}

The soil sample was taken from the Cyperus rotundus rhizosphere of Cemoro Sewu highland, Magetan District, East Java, Indonesia (1920 m asl.). The soil was collected from three sites and placed in a sterile plastic bag.

\section{Isolation, purification of Streptomyces sp. CRB46}

Streptomyces sp. CRB46 was isolated from soil samples on Raffinosa-Histidine Agar (RHA) media using spread plate method. Purification of Streptomyces sp. CRB46 was performed on Starch-Casein Agar (SCA) by streak plate method.

\section{Test microorganisms}

A total of 12 test microorganisms were used in this study. Staphylococcus aureus ATCC 25923, Staphylococcus epidermidis ATCC 12228, Bacillus subtilis FNCC 0060, Bacillus cereus, Bacillus alvei, and Bacillus licheniformis were representing Gram-positive bacteria. Escherichia coli ATCC 35281, Salmonella typhimurium ATCC 14028, Pseudomonas aeruginosa ATCC 35281, Klebsiella pneumoniae ATCC 33495 and Proteus vulgaris ATCC 49132 were representing Gram-negative bacteria and Candida albicans was representing fungi.

\section{Antimicrobial activity of Streptomyces sp. CRB46 extracts}

Primary screening test for antimicrobial activities of Streptomyces sp. CRB46 was carried out on four test microorganisms, namely: S. aureus ATCC 25923, B. subtilis FNCC 0060, E. coli ATCC 35281, and C. albicans. The test was carried out using block agar method with a diameter of $6 \mathrm{~mm}$ (Nedialkova and Naidenova 2005). Further screening was done by testing the activity of the ethyl acetate extracts of supernatant (extracellular) and pellet (intracellular) of Streptomyces sp. CRB46 on 12 test microorganisms using the paper disc dilution method (6 mm paper diameter).

Crude extracts were firstly diluted by adding absolute ethanol. Dilution was carried out both on extracellular and intracellular extracts of Streptomyces sp. CRB46 with a final concentration of $5 \mathrm{mg} / \mathrm{mL}$. Paper disc was then dropped with extract volume of $10 \mu \mathrm{L}$ respectively and placed on one of the quadrants on a petri dish containing Nutrient Agar media inoculated with a test microorganism. Absolute ethanol was used as the negative control, while antibiotic chloramphenicol and streptomycin (PA with $98 \%$ concentration, respectively) were used as the positive controls. All cultures were then incubated at $30{ }^{\circ} \mathrm{C}$ for 24 hours. The level of inhibition, marked by the formation of inhibition zone, were then categorized. If the diameter of the inhibition zone was $7-15 \mathrm{~mm}$, the inhibitory activity was categorized as weak, $16-25 \mathrm{~mm}$ as moderate, while more than $25 \mathrm{~mm}$ was considered as strong (Nedialkova and Naidenova 2005).

\section{Identification of Streptomyces sp. CRB46}

Streptomyces sp. CRB46 was identified based on cell and colony morphology by Gram staining procedure (Prescott 1999). Molecular identification of Streptomyces sp. CRB46 was carried out by $16 \mathrm{~S}$ rDNA sequencing and further confirmed by whole-genome sequencing. DNA isolation was carried out as described by Magarvey et al. (2004). DNA sequencing was carried out at First BASE Laboratories Bhd, Selangor, Malaysia. The purification of PCR products was carried out by using PCR purification kit of the BigDye ${ }^{\circledR}$ Terminator KIT v3.1 Cycle Sequencing Kit. The sequencing was conducted by using ABI PRISM 3730xl Genetic Analyzer Applied Biosystems, USA).

\section{Cultivation and extraction of bioactive compound (antibiotics)}

Three grams of cell pellets of Streptomyces sp. CRB46 was inoculated into $300 \mathrm{~mL}$ of Raffinosa Histidine broth. The culture was incubated with shaking at $160 \mathrm{rpm}, 28^{\circ} \mathrm{C}$ for ten days (Alimuddin et al. 2010; Charousova et al. 2015). After ten days, the pellets and supernatants were separated by centrifugation at $4000 \mathrm{rpm}, 4^{\circ} \mathrm{C}$ for 35 minutes. Both pellets and supernatant were stored for intracellular and extracellular antibiotics extraction.

Both intracellular (pellet) and extracellular (supernatant) antimicrobial substances were extracted using ethyl acetate $(1: 1 \mathrm{v} / \mathrm{v})$ as the solvent. Pellet cells were crushed with a mortar followed by the addition of $5 \mathrm{~mL}$ ethyl acetate. The mixture was shaken overnight and centrifuged at $4000 \mathrm{rpm}$ for 35 minutes at $4{ }^{\circ} \mathrm{C}$ to separate the cell debris from the ethyl acetate phase. The mixture of supernatant and the solvent was shaken for one hour and kept stationary for 15 minutes to separate the organic phase and the water phase. Furthermore, the organic phase of intracellular and extracellular solvent extract were evaporated in a water bath at $80^{\circ} \mathrm{C}$ (Retnowati et al. 2018). Both crude extracts were then diluted with absolute ethanol. The percentage of yield extract were calculated using the formula: Extract yield \% = R/S x 100 (where R; weight of crude extract, $\mathrm{S}$; weight of the pellet or volume of supernatant (Mostafa et al. 2018).

\section{TLC of supernatant extract and bioautography assay}

Five $\mathrm{mg}$ of dried crude extracts of ethyl acetate supernatant and ethyl acetate extract of cell pellets of 
CRB46 were diluted with $1 \mathrm{~mL}$ absolute ethanol. Subsequently, $10 \mu \mathrm{L}$ of diluted extracts were dropped on to GF254 silica gel plate as the stationary phase, with capillary pipes. Prior to use, the GF254 silica gel plate was first cut to size $10 \times 20 \mathrm{~cm}$ and activated by heating it at $120{ }^{\circ} \mathrm{C}$ for 60 minutes). The GF254 silica gel plate was then eluted in a TLC vessel, which contained chloroformmethanol $(4: 1 \mathrm{v} / \mathrm{v})$ as the mobile phase. After the solvent reached the specified height limit, the TLC plate was removed and dried. The presence of spots on the TLC chromatogram was visualized under UV light with $\chi 254$ and $366 \mathrm{~nm}$ (Naikpatil and Rathod 2011).

The bioautography assay was carried out by attaching the TLC chromatogram plate onto the surface of the Nutrient Agar medium, which had been inoculated with 12 test microorganisms as used for antimicrobial activity of EAS and EAP extracts. The TLC chromatogram plates were contacted for 20 minutes, followed by incubating the culture $37^{\circ} \mathrm{C}$ for 24 hours after removing the TLC plate. The formation of the inhibition zone as influenced by the spot on to the test microorganisms was observed. The location of the inhibition zone was matched with the spot position on the TLC plate, and the Rf value was calculated (Gulve and Deshmukh 2012; Shetty et al. 2014).

\section{LCMS analysis of bioactive compounds}

The quantitative bioactive compound analysis on EAS and EAP extracts was carried out with LCMS. Five $\mu \mathrm{L}$ of sample was centrifuged at maximum speed, followed by injection into a Shimadzu single quadrupole LCMS-201 0A mass spectrometer. The compounds were separated in ACQUITY UPLC @ BEH C18 $1.7 \mu \mathrm{m}$ column using a gradient of solvent $\mathrm{A}(0.1 \%$ formic acid in water $)$ and solvent B (0.1\% formic acid in acetonitrile). Flow speed was set $0.35 \mathrm{~mL} /$ minute; $0.01-0.5$ minutes $15 \% \mathrm{~B}, 0.5-7$ minutes $15-95 \% \mathrm{~B}, 7-8$ minutes $95 \% \mathrm{~B}, 8-8.2$ minutes 95 $15 \%$ B, 8.2-15 minutes $15 \%$ B. Mass spectra (mz) were obtained in positive ion mode with capillary voltage at 3.5 kV (Retnowati et al. 2018).

\section{FTIR analysis of bioactive compounds}

The analysis of functional group of bioactive compounds in EAS extract was carried out by using FTIR as described in the Thermo Scientific Nicolet iS10 FTIR tool.

\section{AntiSMASH analysis to predict the chemical structures of the bioactive compounds}

The prediction of the chemical structures of bioactive compounds produced by Streptomyces sp. CRB46 was performed using AntiSMASH software (Blin et al. 2019) based on the whole-genome sequencing of Streptomyces sp. CRB46.

\section{RESULTS AND DISCUSSION}

Isolation and Identification of Streptomyces sp. CRB46

Streptomyces sp. CRB46 was one of 31 isolates Streptomyces isolated from Cyperus rotundus L. rhizosphere in the Cemoro Sewu highland grown on RHA media. The colony diameter of Streptomyces sp. CRB46 ranges from 6-8 $\mathrm{mm}$, circular form, flat elevation, and entire margin. Streptomyces sp. CRB46 was a branching rod, purple and Gram-positive bacteria.

Based on the $16 \mathrm{~S}$ rDNA sequencing, Streptomyces sp. CRB46 (NCBI accession number: MN784503) was confirmed as sister clade and identical with Streptomyces rochei strain NRRL B 2410 with a 100\% similarity level. The whole genomes sequencing data, however, showed that the similarity level of Streptomyces sp. CRB46 with Streptomyces rochei strain NRRL B 2410 was only $95.31 \%$.

\section{Primary screening for bioactivity of Streptomyces sp. CRB46}

Based on the primary screening test for antimicrobial activities, it was observed that Streptomyces sp. CRB46 capable of inhibiting the Staphylococcus aureus (S. aureus) ATCC 25923 growth with diameter of inhibition zone was $15 \mathrm{~mm}$ and Candida albicans of $30 \mathrm{~mm}$.

\section{Streptomyces sp. CRB46 extraction yield}

One of the principles in the extraction process is that polar compounds are dissolved using polar compounds, and vice versa, non-polar compounds are dissolved in non-polar compounds, so that all bioactive compounds can be dissolved in solvents. However, the nature of bioactive compounds produced by Streptomyces sp. CRB46 has not yet been identified. Therefore, semi-polar ethyl acetate was chosen as a solvent in extraction, both for EAS and EAP extraction. Previous studies also used ethyl acetate as the solvent in the extraction of Actinomycetes from rhizosphere soil from mangrove (Retnowati et al. 2018), Streptomyces omiyaensis SCH2 from mangrove sediment (Tangjitjaroenkun 2018) and Actinomycetes from maize rhizosphere soil in Nusa Tenggara Timur (Apsari et al. 2019). The percentage yield of EAS extract was $20 \%$, much higher than the percentage yield $(2.89 \%)$ of EAP extract.

\section{Antimicrobial activity of Streptomyces sp. CRB46 extracts}

The antimicrobial activity of extracts is presented in Table 1 and Figure 1. Table 1 showed that the highest antimicrobial activity was against Gram-positive bacteria, despite the fact that almost all of test bacteria were inhibited by the EAS crude extract as demonstrated by the diameter of inhibition zone which is in the range of $17-35 \mathrm{~mm}$.

Table 1 shows that the negative control, absolute ethanol (98\%) used to dilute the extract, did not exhibit any antimicrobial activities to all test microorganisms. Ethanol is volatile organic alcohol (flash point, $13{ }^{\circ} \mathrm{C}$ ), therefore it rapidly evaporated after being dropped on a paper disc (Chatterjee et al. 2006). Therefore, it is clear that the inhibition of test microorganisms was caused by the bioactive compounds contained in the extract, not the solvent. In positive control, two standard antibiotics were used, i.e. chloramphenicol and streptomycin. The results showed that both chloramphenicol and streptomycin inhibited all test bacteria, except $S$. epidermidis ATCC 12228, which was not inhibited by streptomycin. In addition, it was also known that chloramphenicol activities were better than streptomycin. 
Table 1 also showed that the antimicrobial activity of EAS crude extract was generally better than EAP crude extract, not only in terms of the antimicrobial spectrum, but also the diameter of inhibition zone. The EAS extract is a potent antibacterial and anticandidal compound, in contrast to the EAP extract which did not exhibit anticandidal activity. The EAS extract was found to inhibit 11 of 12 tested microorganisms with a diameter of the inhibition zone ranging from $17-35 \mathrm{~mm}$, while the EAP extract was only able to inhibit the growth of seven test microorganisms (16-26 mm). It was also found that only $K$. pneumoniae ATCC 33495 which was not inhibited by EAS extract. Previous study, however, showed that antibacterial activity of intracellular crude extract of two potential strains of Actinomycetes were higher than the extracellular extract (Retnowati et al. 2018).

The EAS extract also inhibited five test microorganisms with the diameter of inhibition zones of more than $25 \mathrm{~mm}$, therefore it is considered as a strong antibacterial compound (Nedialkova and Naidenova 2005). The five test microorganisms inhibited by the EAS extract were $S$. aureus ATCC 25923 (34 mm inhibition zone), B. subtilis FNCC 0060, and P. aeruginosa ATCC 27853 (26 $\mathrm{mm}$ of inhibition zones), B. licheniformis $(27 \mathrm{~mm})$ and $C$. albicans (35 mm).
Table 1. Antimicrobial activity of ethyl acetate extract of Streptomyces sp. CRB46

\begin{tabular}{|c|c|c|c|c|}
\hline \multirow[b]{2}{*}{ Test microorganisms } & \multicolumn{4}{|c|}{$\begin{array}{c}\text { Diameter of the inhibition } \\
\text { zone (mm) }\end{array}$} \\
\hline & 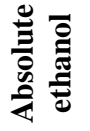 & 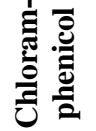 & 旁导 & 초 \\
\hline
\end{tabular}

$\begin{array}{lccccc}\text { S. aureus ATCC } 25923 & - & 36 & 30 & 25 & 34 \\ \text { S. epidermidis ATCC } 12228 & - & 27 & - & 22 & 23 \\ \text { B. subtilis FNCC } 0060 & - & 39 & 28 & 21 & 26 \\ \text { B. cereus } & - & 30 & 30 & - & 17 \\ \text { B. alvei } & - & 30 & 33 & 16 & 25 \\ \text { B. licheniformis } & - & 47 & 35 & 26 & 27 \\ \text { E. coli ATCC } 35281 & - & 45 & 35 & - & 23 \\ \text { S. typhimurium ATCC } 14028 & - & 33 & 36 & 20 & 25 \\ \text { P. aeruginosa ATCC 27853 } & - & 35 & 30 & 21 & 26 \\ \text { K. pneumoniae ATCC 33495 } & - & 17 & 30 & - & - \\ \text { P. vulgaris ATCC49132 } & - & 47 & 38 & - & 25 \\ \text { C. albicans } & - & - & - & - & 35\end{array}$

Note: Negative control: absolute ethanol, positive control I: chloramphenicol, positive control II: streptomycin, EAP: pellet ethyl acetate extract (intracellular), EAS: supernatant ethyl acetate extract (extracellular)
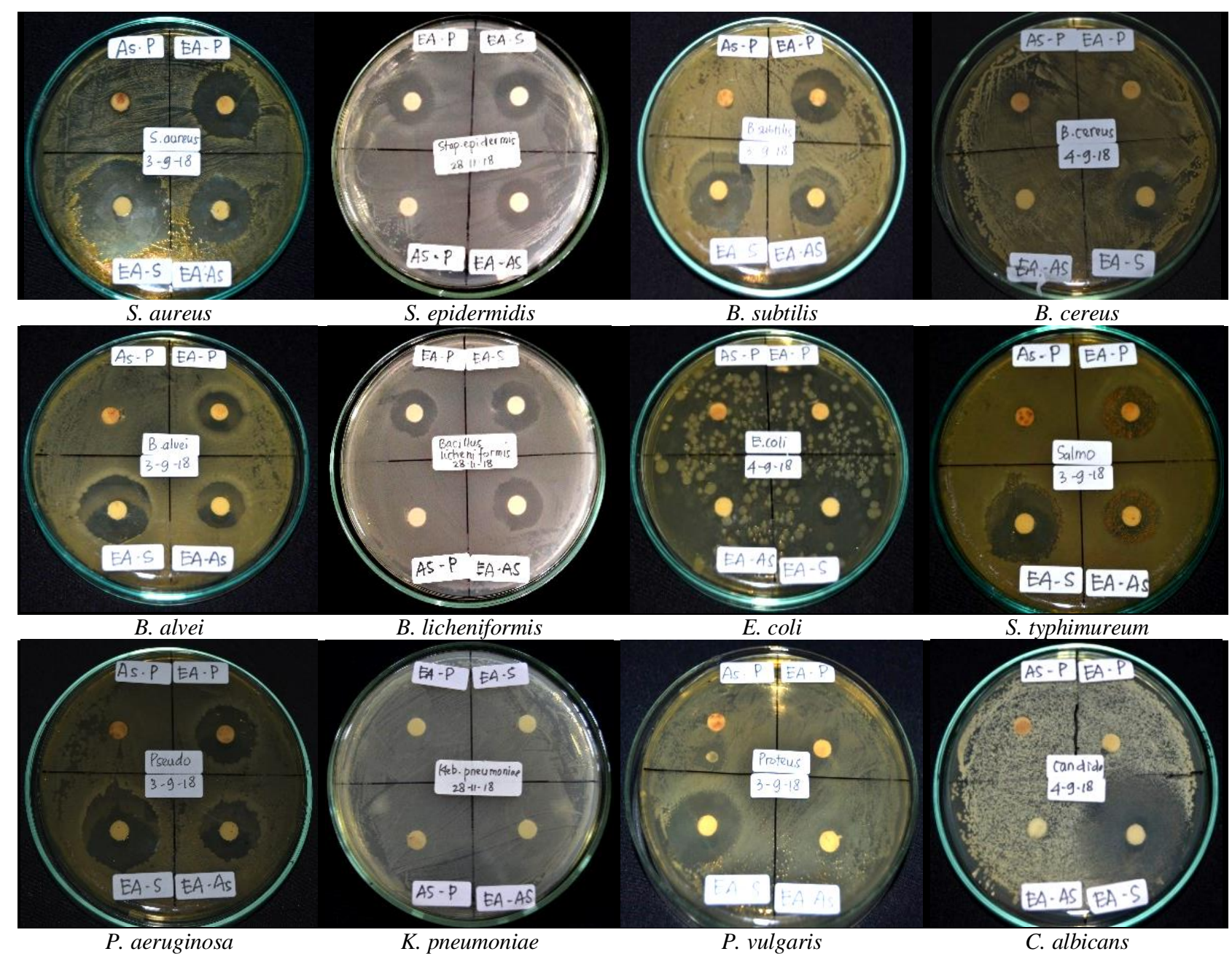

Figure 1. Antimicrobial activity of Streptomyces sp. CRB46 extracts toward test microorganisms 
On the other hand, only one bacterium was inhibited by EAP extract with a strong category, i.e. B. alvei $(26 \mathrm{~mm}$ inhibition zone) (Figure 1). Nevertheless, the inhibition zone by EAS extract was smaller than the two standard antibiotics. Similarly, previous work demonstrated that the antibacterial activity of Actinomycetes crude extract was lower than the antibacterial activities of standard antibiotics, such as ampicillin and chloramphenicol (Retnowati et al. 2018). Mode of action of antibiotics produced by Streptomyces, like tetracycline, spectinomycin streptomycin, kanamycin, and gentamicin is through the inhibition of protein synthesis (Procopio et al. 2012).

\section{The active compound in secondary metabolite crude} extract

The spot profiles of the bioactive compound from the EAS extract in the TLC chromatogram and their bioautography results are presented in Figure 2. Figure 2 demonstrates that eight spots in the TLC chromatogram of EAS crude extract (A) and five spots of EAP crude extract (B), suggest the inhibiting feature on some test bacteria. Inhibition was not only against Gram-positive bacteria but also against Gram-negative bacteria. Spot on the EAS extract was capable of inhibiting five test bacteria, including $S$. aureus ATCC 25923, B. subtilis FNCC 0060, and B. licheniformis (Gram-positive) and S. typhimurium ATCC 14028 and P. aeruginosa ATCC 27853 (Gramnegative) with a large inhibition zone. On the other hand, spot-on EAP crude extract only inhibited two test bacteria, i.e. B. subtilis FNCC 0060 and S. typhimurium ATCC 14028 with smaller inhibition zones. Previous work (Retnowati et al. 2018), demonstrated that crude extract of an Actinomycetes isolated from the rhizosphere soil of the Torosiaje mangrove forest, Gorontalo, was found only inhibited the growth of $S$. aureus.

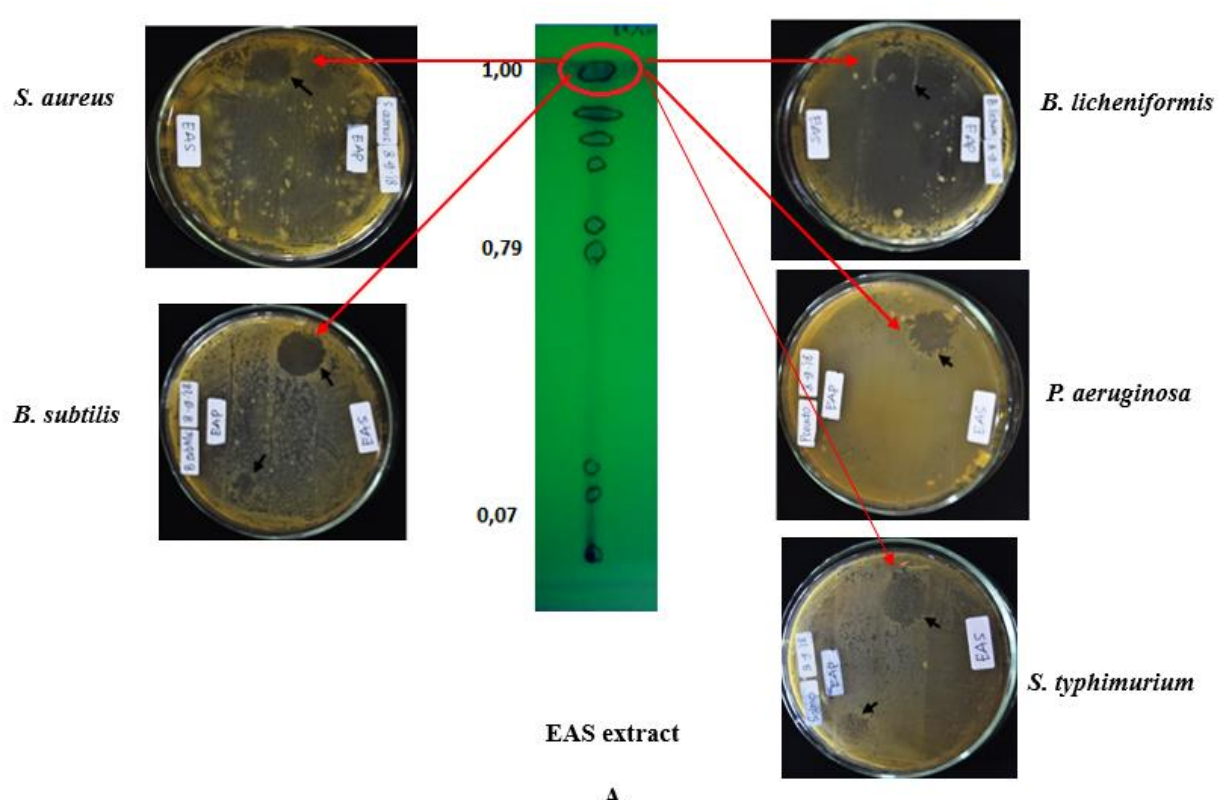

A

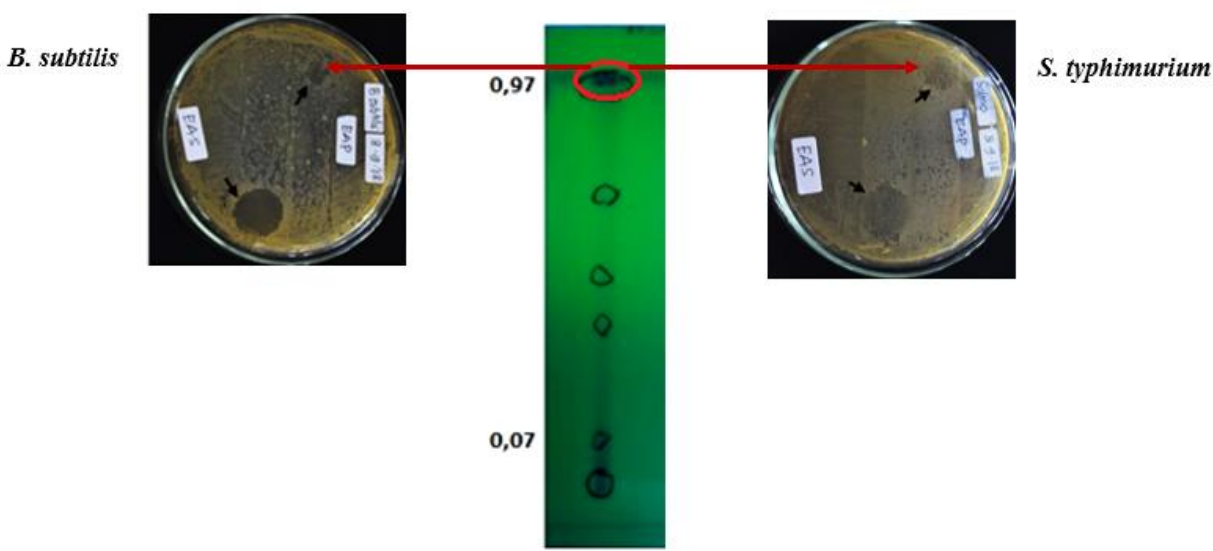

EAP extract

B

Figure 2. Bioautography results from the EAS and EAP crude extracts of Streptomyces sp. CRB46 
Based on the bioautography, it is estimated that the spot of the EAS crude extract chromatogram that inhibited the test bacteria had an Rf of 1.00 and, while the EAP crude extract had an RF of 0,97 . Similar results were also found with the actinomyces isolate (FUAm2-h1 strain) from Torosiaje mangrove forest, Gorontalo, which had an Rf of 0.94 (Retnowati et al. 2018). The bioautography test also supports the results of antimicrobial activity analysis that EAS demonstrated better inhibitory effect than EAP, thus confirmed that potential bioactive compounds from Streptomyces sp. CRB46 was found extracellularly. Supernatant extracts of Streptomyces sp. VITBRK2, isolated from marine sediments in Chennai, Tamil Nadu,
India, was also shown to have more potential activity in inhibiting test bacteria than the intracellular compounds (Rajan and Kannabiran 2014). Similarly, supernatant extracts of Streptomyces sp. ERI-15 isolated from soil in India also showed potential as an antimicrobial (Ignacimuthu et al. 2017).

\section{Characters and identity of the active compounds}

The spectrum of bioactive compounds based on separation with LCMS of EAS and EAP crude extracts are presented in Figure 3 while the functional group analysis with FTIR is presented in Figure 4.

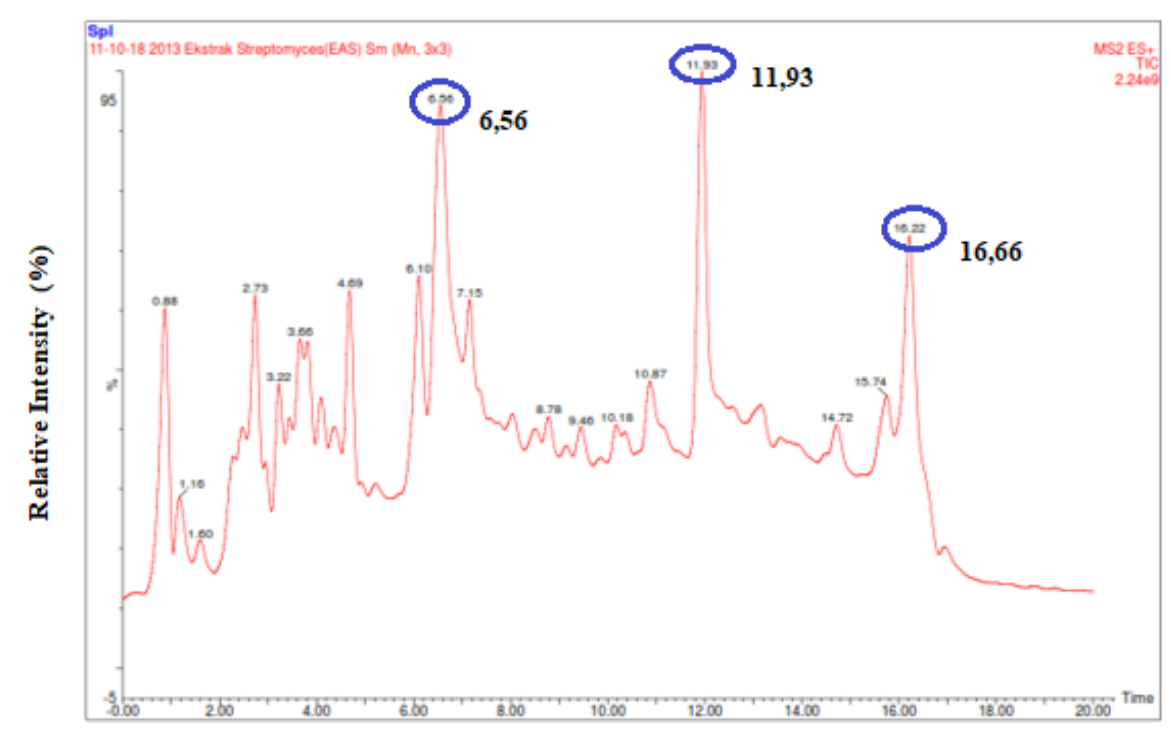

Retention Time (Minutes)

A

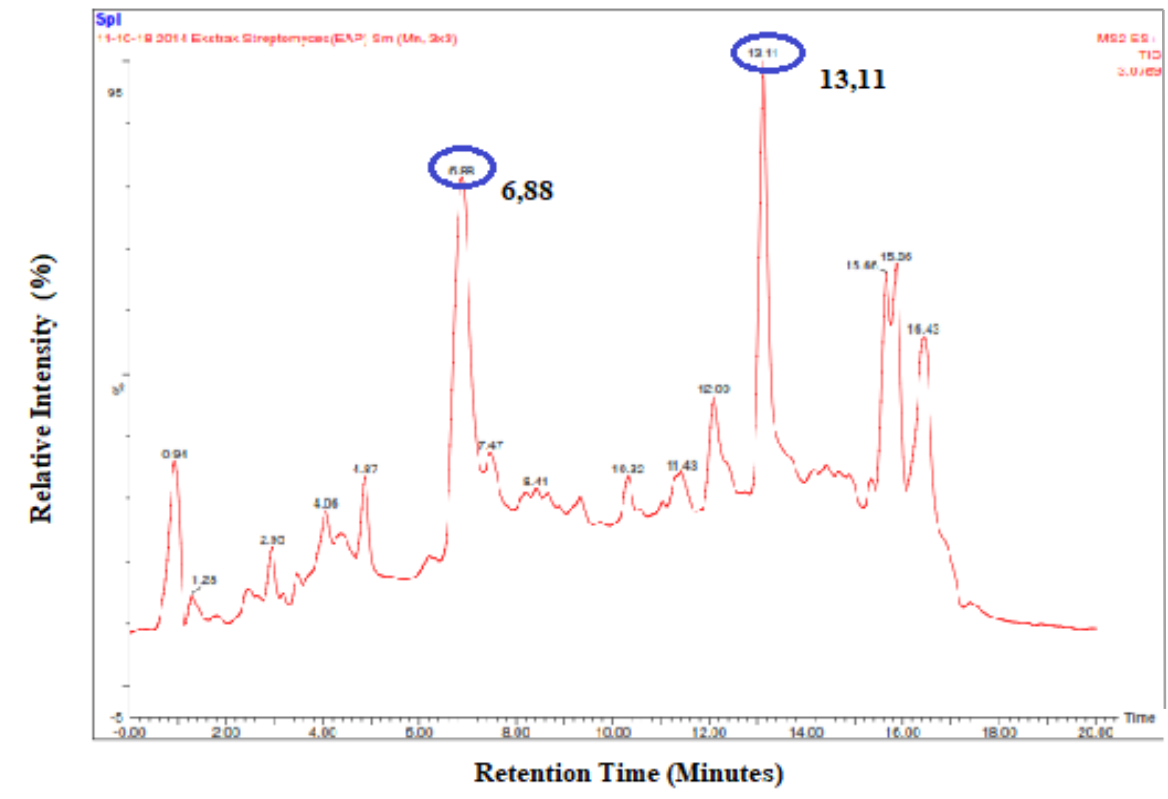

B

Figure 3. LCMS Chromatogram from EAS and EAP crude extracts of Streptomyces sp. CRB46 


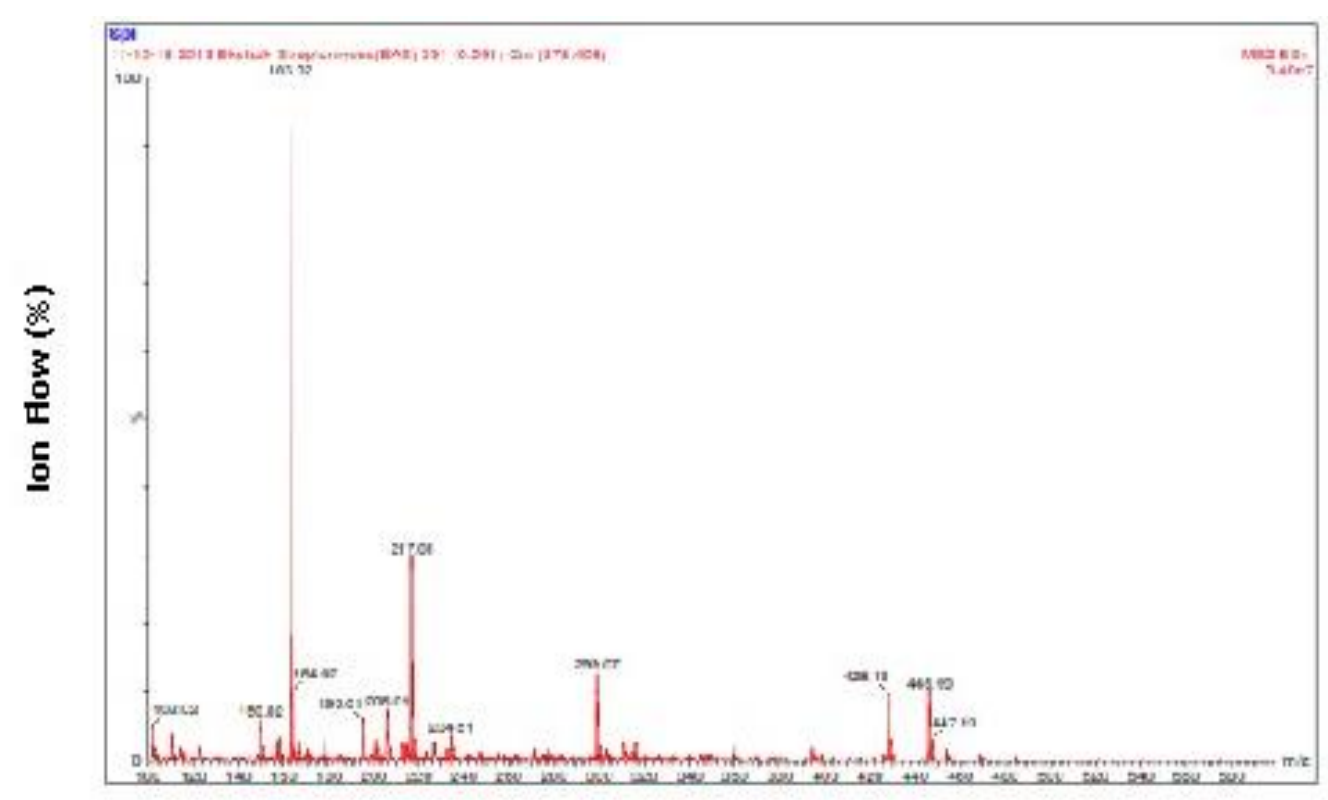

Molecular Mass (M/Z)

Figure 4. Spectral mass of retention time of 6.56 minutes

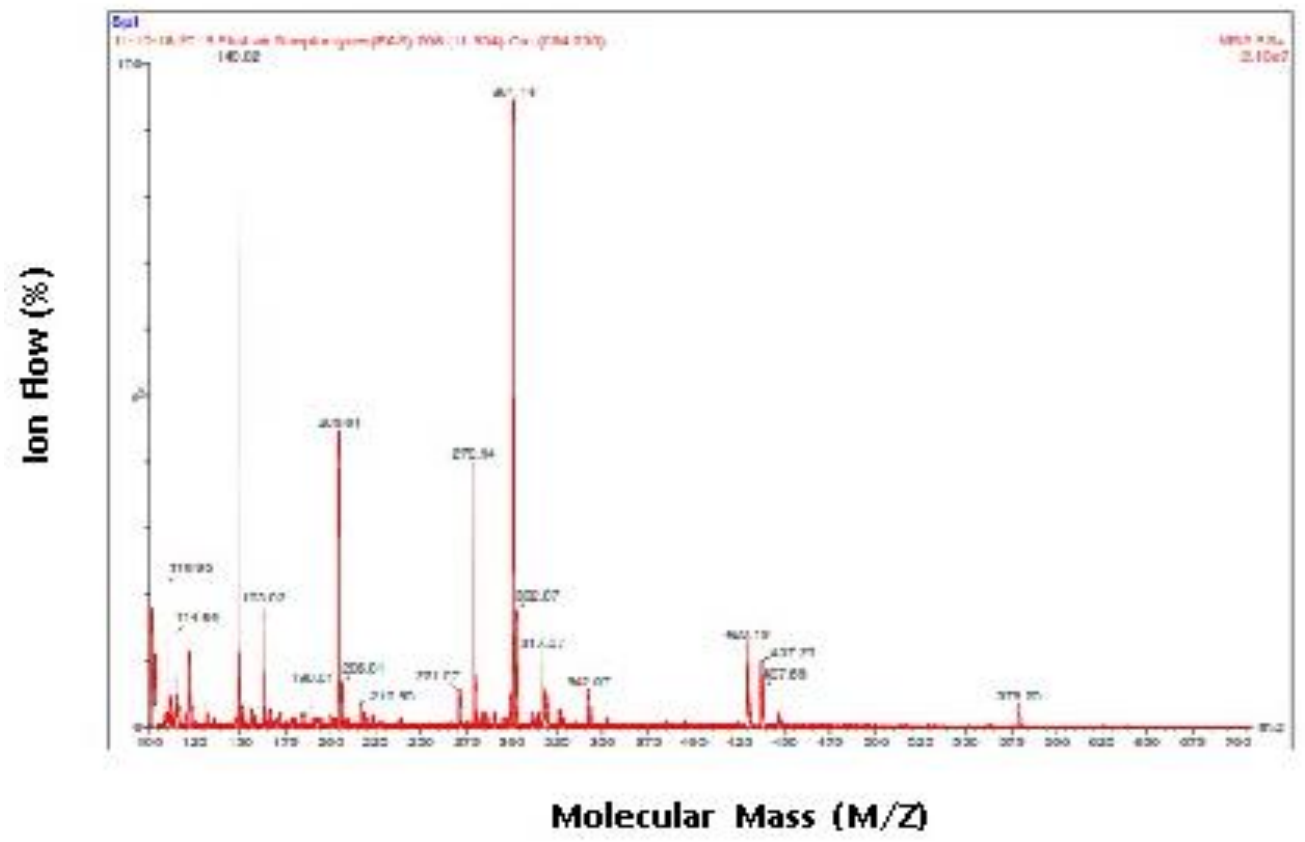

Figure 5. Spectral mass of retention time of 11,93 minutes

Figure 3 shows that EAS crude extract had a bioactive compound consisting of 20 mixtures of organic compounds (20 peaks). Among 20 compounds, three highest peaks were observed depicting the main compounds. The first main compound (first peak) was detected with a retention time of 6.56 minutes (Figure 4), with a molecular weight of $163.02 \mathrm{~g} / \mathrm{mol}$. The second main compound (second peak) had a retention time of 11.93 minutes (Figure 5), with a molecular weight of $149.02 \mathrm{~g} / \mathrm{mol}$ and $301.14 \mathrm{~g} / \mathrm{mol}$. While the third main compound (third peak) was detected at 16.22 minutes (Figure 6), with molecular weights of 111.02 $\mathrm{g} / \mathrm{mol}$ and $239.20 \mathrm{~g} / \mathrm{mol}$. The EAP crude extract, however, only consists of 15 mixtures of organic compounds with two main compounds with the retention time of 6,88 minutes with molecular weight of $163,02 \mathrm{~g} / \mathrm{mol}$ and 13,11 minutes $(149,02 \mathrm{~g} / \mathrm{mol})$. 
Table 2. The functional groups in the extracellular (EAS) extracts of Streptomyces sp. CRB46

\begin{tabular}{cccll}
\hline $\begin{array}{c}\text { Frequency } \\
\text { range }\left(\mathbf{c m}^{\mathbf{1}} \mathbf{)}\right.\end{array}$ & $\begin{array}{c}\text { Absorbance } \\
\text { EAS }\left(\mathbf{c m}^{\mathbf{1}} \mathbf{)}\right.\end{array}$ & $\begin{array}{c}\text { Absorption } \\
\text { range }\left(\mathbf{c m} \mathbf{-}^{\mathbf{1}}\right)\end{array}$ & $\begin{array}{c}\text { Functional } \\
\text { group }\end{array}$ & Compound class \\
\hline $4000-3000$ & 3318.72 & $3350-3310$ & $\mathrm{~N}-\mathrm{H}$ & Secondary amine \\
$3000-2500$ & 2972.73 & $3000-2840$ & $\mathrm{C}-\mathrm{H}$ & Alkane \\
& 2928.72 & $3000-2840$ & $\mathrm{C}-\mathrm{H}$ & Alkane \\
$2400-2000$ & 2881.73 & $3000-2840$ & $\mathrm{C}-\mathrm{H}$ & Alkane \\
$2000-1650$ & 2128.88 & $2160-2120$ & $\mathrm{~N}=\mathrm{N}=\mathrm{N}$ & Azide \\
& 1925.55 & $2000-1650$ & $\mathrm{C}-\mathrm{H}$ & Aromatic compound (overtone) \\
$1600-1300$ & 1659.29 & $1690-1640$ & $\mathrm{C}-\mathrm{N}$ & Imine/okime \\
$1400-1000$ & 1451.69 & 1465 & $\mathrm{C}-\mathrm{H}$ & Alkena (methylene group) \\
& 1418.15 & $1400-1395$ & $\mathrm{O}-\mathrm{H}$ & Carboxylic acid \\
& 1379.64 & $1390-1310$ & $\mathrm{O}-\mathrm{H}$ & Phenol \\
& 1327.95 & $1342-1266$ & $\mathrm{C}-\mathrm{N}$ & Aromatic amine \\
& 1274.16 & $1275-1200$ & $\mathrm{C}-\mathrm{O}$ & Alkyl, aryl, ether \\
& 1087.10 & $1124-1087$ & $\mathrm{C}-\mathrm{O}$ & Secondary alcohol \\
& 1045.24 & $1050-1040$ & $\mathrm{CO}-\mathrm{O}-\mathrm{CO}$ & Anhydride \\
& 879.73 & & $\mathrm{C}-\mathrm{H}$ & 1,3 -disubstituted/1,2,4-trisubstituted benzene \\
& 802.64 & $810 \pm 20$ & $\mathrm{C}-\mathrm{H}$ & 1,4 disubstituted/1,2,3,4 tetrasubstituted benzene \\
\hline
\end{tabular}

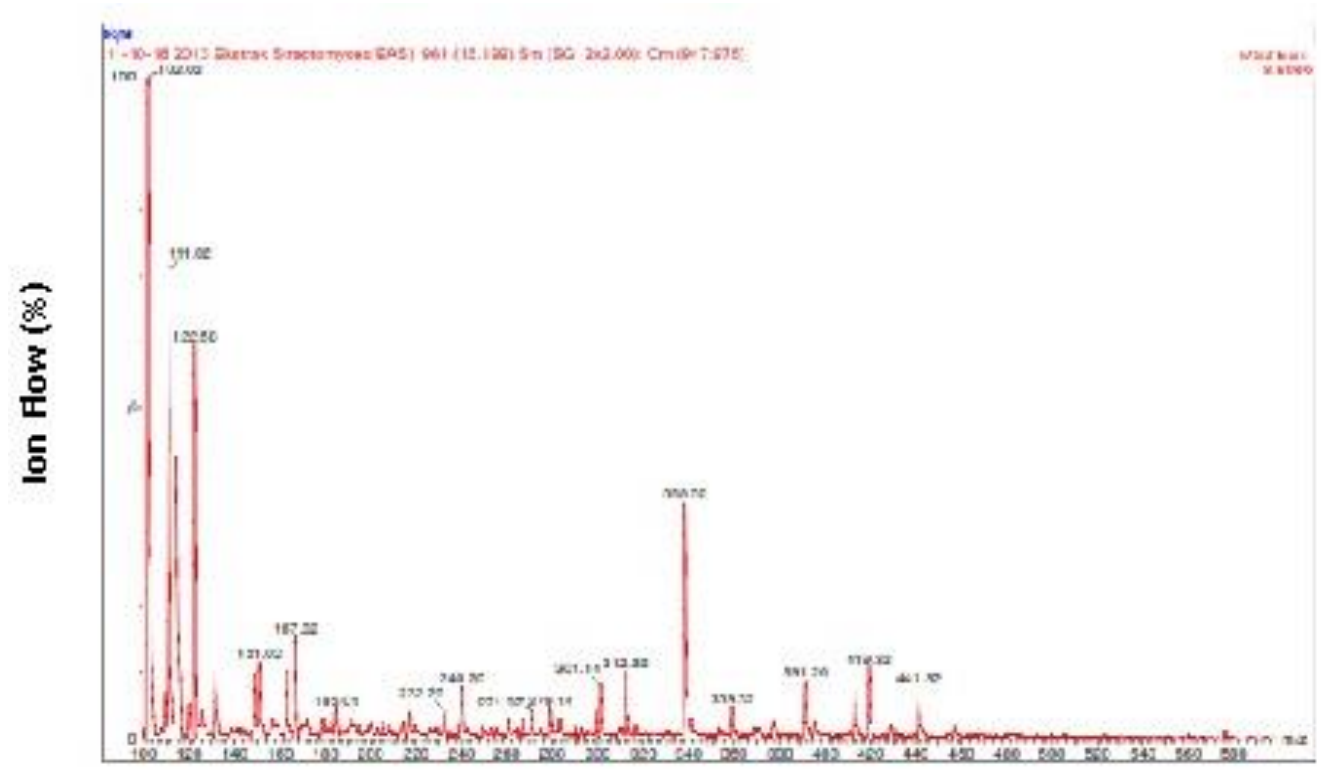

Molecular Mass (M/Z)

Figure 6. Spectral mass of retention time of 16,22 minutes

The FTIR analysis (Figure 7) shows that EAS extract had an IR spectrum of 16 peaks. It is shown in Table 2 that the range of absorbance values at EAS extract is within the range of 3318.72 to $802.64 \mathrm{~cm}^{-1}$, while the functional groups of EAS extract include $\mathrm{N}-\mathrm{H}, \mathrm{C}-\mathrm{H}, \mathrm{N}=\mathrm{N}=\mathrm{N}, \mathrm{O}-\mathrm{H}$, $\mathrm{C}-\mathrm{N}, \mathrm{C}-\mathrm{O}$, and $\mathrm{CO}-\mathrm{O}-\mathrm{CO}$.

The functional groups show that the compounds can be classified into amines, alkanes, aromatic compounds, imines/okime, carboxylic acids, phenols, aromatic amines, alkyl, aryl, ether, secondary alcohols, anhydrides, 1,3substituted/1,2,4,4 substituted benzene and 1.4 substituted/1,2,3,4 tetrasubstituted benzene. Similar results were also reported by Retnowati et al. (2018), despite the fact that some differences were also observed, particularly in terms of the functional groups.
Prediction of bioactive compounds produced by Streptomyces sp. CRB46 and their chemical structures

The advances in bioinformatics technology make it possible to predict the chemical structure of compounds produced by Streptomyces, by analyzing sequences of whole-genome sequencing by using AntiSMASH software (Blin et al. 2019). The results of AntiSMASH 5.00beta1ca06418 analysis, demonstrated that Streptomyces sp. CRB46 produced eight types of bioactive compounds with $100 \%$ similarity to other compounds found in Streptomyces species. It, therefore, can be ascertained that Streptomyces sp. CRB46 produced all of eight secondary metabolites, i.e. SAL-2242 (lanthipeptide), albaflavenone (terpene), isorenieratene (terpene), geosmin (terpene), 7-prenilisatine (other), ectoine (other), melanin (other) dan micromonolactam (PKS-1). Nevertheless, of the eight 
compounds, only six compounds had their chemical structure known. The predicted chemical structures of the six compounds are presented in Figure 5.

Geosmin compound produces an earthy-musty odor, a smell like freshly-plowed soil, which is one of the characteristics of Streptomyces (Pan et al. 2009; Hikida et al. 2011). Geosmin is a volatile metabolite (Jüttner and Watson 2007), produced by Streptomyces coelicolor A3(2) (Jiang et al. 2007) which does not have any antibiotic activity (Seipke et al. 2012). Ectoine is synthesized by bacteria in response to high salinity or osmolarity and or extreme growth temperatures (Czech et al. 2018). Ectoine produced by Streptomyces can act as an antifungal and inhibit the growth of Phytophthora drechsleri (Sadeghi et al. 2017). The ectoine (other) compound can also be found in S. anulatus (Prabhu et al. 2004).

Albaflavenone (terpene) is a sesquiterpene antibiotic produced by S. coelicolor A3(2) (Zhao et al. 2008; Lin and Chane 2009). Melanin has antibacterial activity and can be applied as a potential natural bacteriostatic agent in food or pharmaceutical industry (Xu et al. 2017). Melanin (other) is also produced by S. coelicolor A3(2) (Bentley et al. 2002).

Isorenierantene (terpene) is an aromatic carotenoid and has antioxidant activity (Chen et al. 2018), synthesized by Streptomyces griseus subsp. griseus NBRC 13350 (Krügel 1999). The 7-prenilisatine (other) compound has the antibacterial activity which inhibits the growth of Bacillus subtilis and is found in Streptomyces sp. MBT28 (Wu et al. 2015).

Micromonolactam is a new polyene macrocyclic compound, found in a marine organism, Micromonospora sp. However, micromonolactam does not have antimicrobial activity, therefore it cannot inhibit the growth of Bacillus subtilis, Mycobacterium smegmatis, Escherichia coli, Candida kefyr, and Aspergillus niger at the concentration of $0.5 \mu \mathrm{g} \mu \mathrm{l}^{-1}$ and $1.0 \mu \mathrm{g} \mu \mathrm{l}^{-1}$ (Skellam et al. 2013).

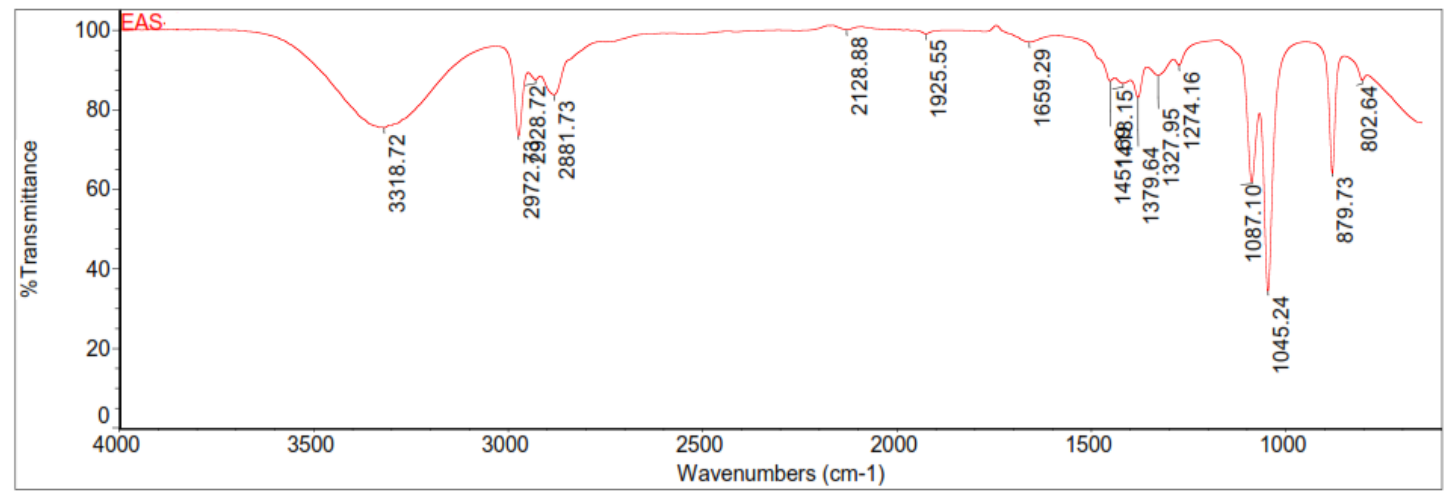

Figure 7. The spectrum analysis of EAS from Streptomyces sp. CRB46 using FTIR

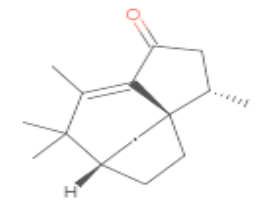

Albaflavenone (terpene) $\mathrm{C}_{15} \mathrm{H}_{22} \mathrm{O}$

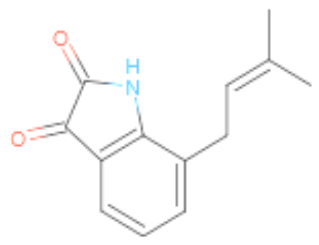

7-prenilisatine (other) $\mathrm{C}_{13} \mathrm{H}_{13} \mathrm{NO}_{2}$<smiles>CC=C(C)C=CC=CC(C)=CC=CC=CC(C)=CC=CC(C)=CC=Cc1c(C)ccc(C)c1C</smiles>

Isorenieratene (terpene) $\mathrm{C}_{40} \mathrm{H}_{48}$

Chiral<smiles>CC(=O)OC(=O)[C@H]1CCN=C(C)N1</smiles>
$\mathrm{C}_{6} \mathrm{H}_{10} \mathrm{~N}_{2} \mathrm{O}_{2}$

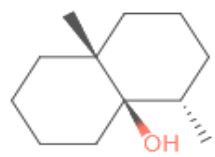

Geosmin (terpene) $\mathrm{C}_{12} \mathrm{H}_{22} \mathrm{O}$<smiles></smiles>

Melanin (other) $\mathrm{C}_{18} \mathrm{H}_{10} \mathrm{~N}_{2} \mathrm{O}_{4}$

Figure 8. Chemical structure of bioactive compounds produced by Streptomyces sp. CRB46 
This study clearly shows that Streptomyces sp. CRB46, isolated from the Cyperus rotundus L. rhizosphere in the Cemoro Sewu highland, has the potential to produce antimicrobial substances of eight classes based on the AntiSMASH analysis. The results also highlight the vast possibilities of exploring the highland habitat as a rich source of bioactive compounds-producing microorganisms.

\section{ACKNOWLEDGEMENTS}

The authors would like to thank the Ministry of Research, Technology, and Higher Education, Indonesia, for providing research funds for Post Graduate Scholarship Program (BPPDN). We are also thankful to Prof. Langkah Sembiring and Prof. Endang Sutariningsih Soetarto for their support during the research as well as to Muhammad Miftahussurur for his assistance in AntiSMASH analysis and Ahmad Fauzi for his assistance in LCMS and FTIR analysis.

\section{REFERENCES}

Alimuddin, Asmara W, Mustofa JW, Nurjasmi R. 2010. An Actinomycetes producing anticandida isolated from Cajuput rhizosphere: Partial identification of isolates and amplification of pksI genes. Indon J Biotech 15 (1): 1-8. DOI: 10.22146/ijbiotech.7817.

Anderson AS, Wellington EMH. 2001. The taxonomy of Streptomyces and related genera. Intl J Syst Evol Microbiol 51: 797-814.

Apsari PP, Budiarti S, Wahyudi AT. 2019. Actinomycetes of rhizosphere soil producing antibacterial compounds against Urinary Tract Infection bacteria. Biodiversitas 20 (5): 2085-4722.

Arifuzzaman M, Khatun MR, Rahman H. 2010. Isolation and screening of Actinomycetes from Sundarbans soil for antibacterial activity. Afr J Biotechnol 9 (29): 4615-4619.

Bentley SD, Chater KF, Cerdeño-Tárraga AM, Challis GL, Thomson NR, James KD, Harris DE, Quail MA, Kieser H, Harper D, Bateman A. 2002. Complete genome sequence of the model Actinomycete Streptomyces coelicolor A3(2). Nature 417 (6885): 141-147. DOI: 10.1038/417141a.

Blin K, Shaw S, Steinke K, Villebro R, Ziemert N, Lee SY, Medema MH, Weber T. 2019. AntiSMASH 5.0: updates to the secondary metabolite genome mining pipeline. Nucleic Acids Res 47 (W1): W81-W87.

Charousová I, Javoreková S, Wink J. 2015. Isolation and characterization of Streptomyces rishiriensis (VY31) with antibiotic activity against various pathogenic microorganisms. J Microbiol Biotechnol Food Sci 4: 23-27.

Chatterjee I, Somerville GA, Heilmann C, Sahl HG, Maurer HH, Herrmann M. 2006. Very low ethanol concentrations affect the viability and growth recovery in post-stationary-phase Staphylococcus aureus populations. Appl Environ Microbiol 72 (4): 2627-2636. DOI: 10.1128/AEM.72.4.2627-2636.2006.

Chen Y, Zhou Y, Chen M, Xie B, Yang J, Chen J, Sun Z. 2018 Isorenieratene interaction with human serum albumin: Multispectroscopic analyses and docking simulation. Food Chem 258: 393-399. DOI: 10.1016/j.foodchem.2018.02.105.

Czech L, Hermann L, Stöveken N, Richter AA, Höppner A, Smits S, Heider J, Bremer E. 2018. Role of the extremolytes ectoine and hydroxyectoine as stress protectants and nutrients: Genetics, phylogenomics, biochemistry, and structural analysis. Genes 9 (4): 177. DOI: 10.3390/genes9040177.

Farnet CM, Zazopoulos E. 2005. Improving drug discovery from microorganisms. In: Zhang L, Demain AL (eds.) Natural Products. Humana Press, New York.
Gulve RM, Deshmukh AM. 2012. Antimicrobial activity of the marine Actinomycetes. Intl Multidiscip Res J 2 (3): 16-22.

Herdini H, Mubarika S, Hariwiyanto B, Wijayanti N, Hosoyama A, Yamazoe A, Nojiri H, Widada J. 2017. Secondary bioactive metabolite gene clusters identification of anticandida-producing Streptomyces sp. GMR22 isolated from Wanagama forest as revealed by the genome mining approach. Indon J Pharm 28 (1): 26-33.

Hikida T, Shimizu K, Umeta T, Utsumi M, Sugiura N. 2011. Influence of environmental factor on musty odor production by Streptomyces coelicolor A3(2). 14th World Lake Conference Lakes, Rivers, Groundwater \& Coastal area: understanding Lingkages Austin. 31 October-4 November 2011. Austin Convention Center, Austin, Texas USA.

Ignacimuthu S, Devadass BJ, Paulraj MG, Theoder AS, Dhabi NA. 2017. Identification of antimicrobial compounds from Streptomyces sp. isolated from western ghats soil in Tamil Nadu. EC Microbiol 8 (4): 222-231.

Jiang J, He X, Cane DE. 2007. Biosynthesis of the earthy odorant geosmin by a bifunctional Streptomyces coelicolor enzyme. Nat Chem Biol 3 (11): 711-715.

Jüttner F, Watson S. 2007. Biochemical and ecological control of geosmin and 2-methylisoborneol in source waters. Appl Environ Microbiol 73 (14): 4395-4406

Korn-Wendisch F, Kutzner HJ. 1992. The family Streptomycetaceae. In the prokaryotes. In: Balows A, Truper HG, Dworkin M, Harder W, Karl-Heinz S (eds.). A Handbook on the Biology of Bacteria: Ecophysiology, Isolation, Identification, Applications. 2nd ed. Springer-Verlag, New York.

Krügel H, Krubasik P, Weber K, Saluz HP, Sandmann G. 1999. Functional analysis of genes from Streptomyces griseus involved in the synthesis of isorenieratene, a carotenoid with aromatic end groups, revealed a novel type of carotenoid desaturase. Biochim Biophys Acta 1439 (1): 57-64. DOI: 10.1016/s1388-1981(99)00075$\mathrm{x}$.

Lazzarini A, Cavaletti L, Toppo G, Marinelli F. 2000. Rare genera of Actinomycetes as a potential producer of new antibiotics. Anton Leeuw Intl J G Mol Microbiol 78 (3-4): 399-405.

Lin X, Cane DE. 2009. Biosynthesis of the sesquiterpene antibiotic albaflavenone in Streptomyces coelicolor mechanism and stereochemistry of the enzymatic formation of epi-isozizaene. J Am Chem Soc 131 (18): 6332-6333.

Madigan MT, Martinko JM, Parker J. 2003. Brock biology of microorganisms. 10th ed. Prentice-Hall, USA.

Magarvey NA, Keller JM, Bernan V, Dworkin M, Sherman DH. 2004. Isolation and characterization of novel marine-derivated Actinomycete taxa rich in bioactive metabolites. Appl Environ Microbiol 70 (12): 7520-7529.

Mostafa AA, Al-Askar AA, Almaary KS, Dawoud TM, Sholkamy EN, Bakri MM. 2018. Antimicrobial activity of some plant extracts against bacterial strains causing food poisoning diseases. Saudi J Biol Sci 25 (2): 361-366.

Naikpatil SV, Rathod JL. 2011. Antimicrobial and cytotoxic activity of Actinomycetes from Karwar coast, west coast of India. World J Sci Technol 1 (1): 07-10.

Nedialkova D, Naidenova M. 2005. Screening the antimicrobial activity of Actinomycetes strains isolated from Antarctica. J Cult Collect 4: 2935.

Okami Y, Hotta K. 1988. Search and discovery of new antibiotics. In: Goodfellow M, Williams ST, Mordarski M (eds.). Actinomycetales in Biotechnology. Academic Press Limited, London.

Pan Y, Xu L, Cao W, Yin S, Wang Z, Zhou Q. 2009. Actinomycetes and earthy-musty odorous compounds in brackish fishponds in Tianjin, China. Water Sci Technol 59 (6): 1185-1194.

Prabhu J, Schauwecker F, Grammel N, Keller U, Bernhard M. 2004. Functional expression of the ectoine hydroxylase gene (thpD) from Streptomyces chrysomallus in Halomonas elongata. Appl Environ Microbiol 70 (5): 3130-3132. DOI: 10.1128/aem.70.5.31303132.2004.

Prescott LM, Harley JP, Klein DA. 1999. Microbiology. 4th ed. WCB McGraw-Hill, Boston.

Procopio RE, Silva IR, Martins MK, Azevedo JL, Araujo JM. 2012. Antibiotics produced by Streptomyces. Braz J Infect Dis 16 (5): 466471. 
Rajan BM, Kannabiran K. 2014. Extraction and identification of antibacterial secondary metabolites from marine Streptomyces sp. VITBRK2. Intl J Mol Cell Med 3 (3): 130-137.

Retnowati Y, Moeljopawiro S, Djohan TS, Soetarto ES. 2018 Antimicrobial activities of actinomycetes isolated from rhizospheric soil on different mangrove forests of Torosiaje, Gorontalo, Indonesia. Biodiversitas 19 (6): 2196-2203.

Sadeghi A, Koobaz P, Azimi H, Karimi E, Akbari AR. 2017. Plant growth promotion and suppression of Phytophthora drechsleri damping-off in cucumber by cellulase-producing Streptomyces. BioControl 62: 805-819. DOI: 10.1007/s10526-017-9838-4.

Seipke RF, Kaltenpoth M, Hutchings MI. 2012. Streptomyces as symbionts: an emerging and widespread theme? FEMS Microbial Rev 36: 862-876. DOI:10.1111/j.1574-6976.2011.00313.x.

Shetty PR, Buddana SK, Tatipamula VB, Naga YVV, Ahmad J. 2014 Production of polypeptide antibiotic from Streptomyces parvulus and its antibacterial activity. Braz J Microbiol 45 (1): 303-312.

Sivalingam P, Hong K, Pote J, Prabakar K. 2019. Extreme environment Streptomyces: Potential sources for new antibacterial and anticancer drug leads? Intl J Microbiol. DOI: 10.1155/2019/5283948.

Skellam EJ, Stewart AK, Strangman WK, Wright JL. 2013. Identification of micromonolactam, a new polyene macrocyclic lactam from two marine Micromonospora strains using chemical and molecular methods: clarification of the biosynthetic pathway from a glutamate starter unit. J Antibiot 66 (7): 431-441.

Tangjitjaroenkun J. 2018. Evaluation of antioxidant, antibacterial, and gas chromatography analysis of ethyl acetate extract of Streptomyces omiyaensis SCH2. Asian J Pharm Clin Res 11 (7): 271-276.

Ullah I, Arshed M, Noureen U, Chuadhry MJI, Jadoon MA. 2012. Isolation of Streptomyces from the sediments of selected thermal springs of northern Pakistan and its intrinsic susceptibility and resistance. Rec Zool Surv Pak 21: 47-50.

Wu C, Du C, Gubbens J, Choi YH, van Wezel GP. 2015. Metabolomicsdriven discovery of a prenylated isatin antibiotic produced by Streptomyces Species MBT28. J Nat Prod 78 (10): 2355-2363.

Xu C, Li J, Yang L, Shi F, Yang L, Ye M, 2017. Antibacterial activity and a membrane damage mechanism of Lachnum YM30 melanin against Vibrio parahaemolyticus and Staphylococcus aureus. Food Control 73 (B): 1445-1451.

Zhao B, Lin X, Lei L, Lamb DC, Kelly SL, Waterman MR, Cane DE. 2008. Biosynthesis of the sesquiterpene antibiotic albaflavenone in Streptomyces coelicolor A3(2). J Biol Chem 283 (13): 8183-8189. DOI: $10.1074 / \mathrm{jbc} . \mathrm{M} 710421200$ 